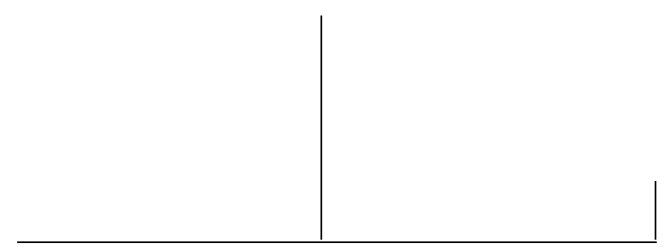

Rev. Latinoam. Psicopat. Fund., VI, 3, 83-93

\title{
Dissolution and enchantment on Erwin Straus' phenomenology of obsession*
}

Federico Leoni

The author presents Erwin Straus' psychopathology of phoby and obsession (with reference to his texts On Obsession, Phenomenology of Hallucinations, and Vom Sinn der Sinne), bringing to light the implications concerning the role of language and gesture in the consistution (and the crisis) of the experiences of subjectivity and objectivity.

Key words: Obsession, phobia, phenomenology, Straus,

language, subject, world

* This text derives from an essay published, in a very different form, as Chapter V of my book Follia come scrittura di mondo. Saggi su Minkowski, Straus, Kuhn (Jaca Book, Milano 2001). Many thanks to the publisher, and to Mrs Judy Baggot for her kind suggestions for this English translation. 


\section{1 - "A flower bouquet was placed on my bed"}

In November 1918, a flower bouquet was placed on my bed. My cousin, who had a charming little boy two years old, took the bouquet from the bed, saying, "It is not right to put flowers on a bed." Three weeks later the child was... From this time on I was very careful never to put flowers on the bed. I am very fond of beautiful flowers, but I cannot touch them any more, and I cannot stand having them in my apartment. But this happened only after I had had a child of my own, who was one and a half years old at that time. I was constantly afraid that the child might be taken from me. In January 1931, a very dear, good old friend, who belonged one could say to our family... His wife, who had hardly any friends and relatives, was with us nearly every Sunday after she had visited the... That wasn't troubling to me at the beginning. Yet, after approximately four to six months I became alarmed by her gloves, later on also by her coat and her shoes. I was careful that none of these things ever came too near to ours. That went on in this way for a while, until the woman noticed it and did not come any more, because she felt I was disgusted. As we live near to the..., I am getting excited about all these people going there. It is a real pilgrimage. If one of these persons touches me I have to clean or wash the particular piece of cloth, either with soap or benzine. If it happens that some of these people enter our home, I cannot move any more. I feel as if the room would get narrower and that I could not avoid touching all the things with my dress. I have to go through the door edgeways. To find peace again I have to wash everything with soap and water. Then everything becomes large and wide, and I can move again. If I do some errands and there is somebody in the store, I cannot go in because they may touch me, or I may get the money which was theirs before. So I am restless all day long, and the restlessness never leaves me. Either I have to wipe things off, or dust, or wash. As soon as I sit down for a while I feel so tired that I fall asleep wherever I am. Nowhere can I find repose. If I ride on the streetcar, I am always worried for fear that somebody may step in, wearing... If that should happen and the woman or the man should take a seat near to me, I should have to get off. Also pictures in newspapers or magazines, where such things are shown, disturb me greatly. If my hand touches such a printed spot, I have 


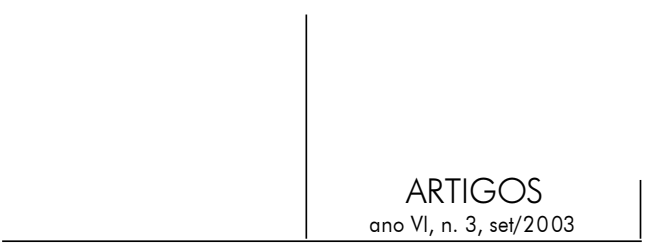

to wash it thoroughly again. I cannot find words enough for all the things which hound me. Inwardly I am constantly in an uproar and for me the saying is true, "there, where you are not, there is rest."

\section{2 - "Waste"}

This ample excerpt from the letter of a patient is reproduced in an essay, entitled On Obsession (1948, p. 7-8), by Erwin Walter Straus - one of the masters, with Karl Jaspers, Eugène Minkowski, Ludwig Binswanger, who gave birth to that vast, variegated body of texts and therapeutic practices known as phenomenological psychopathology and psychiatry.

The category of the repulsive and the disgusting encloses, in Straus' interpretation, the heart of the obsessive and the phobic world, ${ }^{1}$ a world crowded with faces and things without name and number, in an endless ambush whose silent sentries are dirt, dust, and germs; a world whose final meaning is the minute interlacing of life and death, the decay, the slow-working corruption and dissolution of bodies and things.

In phobia and obsession, as Straus notices, death is, in fact, not the radical other of life - the pure and shar lines of a skeleton, dreadful but not actually nauseating - but the other in life: its "inner polarity", Straus says, so absolutely close to life that it is repulsive, repugnant, repellent.

In our talk and in our thoughts we oppose life to death, and in opposing one to the other we separate them, as if they were two different entities. In the living organism, however, life and death are closely interwoven. The skin, in growing, in rejuvenating itself, produces its own waste. So do all other organs. The more vigorous the vital processes, the more luxuriant the bodily functions, the greater the waste.

Waste, here is, then, the Schlüsselwort of Straus's analysis. It is precisely the obscure notion of this exhausted and inexhaustible life, what the experience of phobia and obsession most intensely and tragically brings to light - and, at the same time, what it fights again and again.

1. Even though he does not deal exhaustevely with this subject, Straus assumes that phobia and obsession, while not superimposable, are in general attendant, closely linked experiences. That is why his interpretation constantly oscillates between the two forms, inside a unitary perspective. On the phenomenological differentiation of the two experiences, the first being conceived as the ground of the second, see the classic essay by V.E. von Gebsattel, Die Welt des Zwangskranken, p. 10-74. 


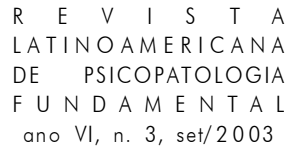

\section{3 - "I cannot find words enough for all the things which hound me"}

In developing his phenomenology, Straus uses clinical material as well as literary works. His essay On Obsession is a sort of gallery swarming with images of diseases, dirt, excretion, from Shakespeare to Swift, from Bosch to Rubens.

He cites the harsh invective of Shakespeare's Tersite who rails against Patroclus in Troilus and Cressida; for Tersite wishes him "the rotten diseases of the south, the gutsgriping, ruptures, catarrhs, loads o' gravel i'the back, lethargies, cold palsies, raw eyes, dirt-rotten livers, wheezing lungs, bladders full of imposthume, sciaticas, limekilns i'the palm, incurable bone-ache, and the rivelled fee-simple of the tetter" (Straus, 1948, p. 18; Shakespeare, 1992).

To Jonathan Swift, whom he judges a phobic temperament, Straus devotes a double quotation. First the repellent receptacle described in The Lady's Dressing Room, in which beautiful Celia lives, crowded with traces of an obscenely teeming, flooding corporeity: "And first a dirty Smock appear'd / Beneath the Arm-pits well besmear'd / ... / Now listen while he next produces, / The various Combs for various Uses, / Fill'd up with Dirt so closely fixt, / No Brush could force a way betwixt. / A Paste of Composition rare, / Sweat, Dandruff, Powder, Lead and Hair..." (Straus, 1948, p. 41) ${ }^{2}$

Then, Straus recalls the description Gulliver offers, in his Travels, of the immense breast of the nurse he met among the gigantic inhabitants of the land of Brobdingnag:

I must confess no object ever disgusted me so much as the sight of her monstrous breast... It stood prominent six foot, and could not be less than sixteen in circumference. The nipple was about half the bigness of my head, and the hue both of that, and the dug so varified with spots, pimples, and freckles that nothing could appear more nauseous... This made me reflect upon the fair skins of our English ladies, who appear so beautiful to us, only because they are of our own size, and their defects not to be seen but through a magnifying glass, where we find by experiment that the smoothest and whitest skins look rough and coarse, and ill coloured. (Ibid., p. 17)

2. J. Swift. The lady's dressing room. We may add that the theme of a conflict between the platonic love for Celia and the recognition of the irreducible animality of the beloved, which finds in The lady's dressing room (1730) a relatively measured expression, explodes only in Cassinus and Petrus (1731), namely when the excremental vision, as Freudian critic N.O. Brown says, becomes obsessive, and the agonizing lover can no longer withdraw his gaze from the scene of Celia defecating: see N.O. Brown, Life against Death. 


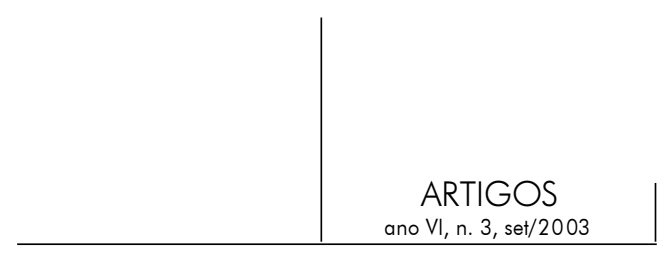

It is hard to compete with the power of these literary images. Aristotle's astonishment is renewed: the repulsive can be the object of such fascinating expression, such enigmatic enchantment of words. But it is not in the power these texts display in identifying and expressing the feelings, the objects, and the colours of disgust that Straus recognizes the secret knot of the experiences of phobia and obsession. It is rather in the impotence of the expression, in what is not said because it is not sayable.

Discussing the letter reproduced in section 1), he firmly grasps this knot. The letter, he writes, testifies to "the theme of many obsessions: death and decay". But it is precisely "the omission of these very words", the omission of the expressions dealing with that theme, that he finds most significant. It reveals "the fear of some magic power" of the word, as if things evoked by words were to gain "an immediate sensory reality" for the patient. The necessity not to speak, the necessity not to say comes from this; and from this comes that strange letter: a texture of rips and voids - blank spaces in which words fall - while the figures of the dreadful multiply their allusions to contagions and corpses.

\section{"... the phobic should be able to give name to what has no language"}

Death, continues Straus, as it is experienced in phobia, "is ubiquitous, amorphous, ungraspable." It has a thousand masks: "I cannot find words enough", says Straus' patient, "for all the things which hound me." A secret bond links the indistinct and the innumerable that proliferate and besiege, the indistinct and the unsayable. The balance between the word and its absence dominate this landscape, as if the dissolution of the world were to coincide with the failure of the word, or this failure with the dissolution of the world, and of its clear order of distinct, distant, nameable objects.

To the hidden power of the word, to its secret struggle with things, to its power of assuming the world giving it its own order - the order of the speakable, the architecture of a sovereign reason - Straus dedicates a memorable passage of his masterpiece, Vom Sinn der Sinne. A man gripped by phobia, he writes, "should be able to give a name" to the object of his terror (1956, p. 205). Then the terror would leave him; then the siege would be raised. "Ein Namen zu geben", he says: the patient should give a name to the void, to the hordes of insects, to the dirt spreading around him, and to the revolting food he is offered. All the terror of the phobia, says Straus, all its obsessive and ineluctable ubiquity, live on and live in this mysterious absence of names.

"As invisible and ungraspable objects", we read in On Obsession, "the germs are the most perfect expression of the omnipresence and the omnipotence 


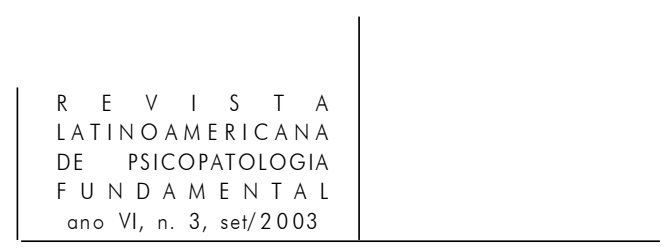

of the dreadful, from which there is no escape" (p. 9) Impossibile, then, for the phobic, to give a name, freeing himself of the object that the name would create, reveal, and keep at a distance. Impossible, for him, to dominate the indistinct by means of the word, and impossible, by means of the word, to dominate himself. The phobic should be able "den Sprachlose ein Namen zu geben", Straus writes in Vom Sinn der Sinne - he should give a name to that which has no language, which is without language, unnameable. But what is sprachlos, without language? What has no words and no names?

\section{4 - "My voice belongs to me; nevertheless, in speaking I hear myself; my voice is reflected back to me and thus far it is similar to a sound which originates from the Other"}

The word, the name - already the voice, the sound, Straus thinks - have peculiar features. Sound, as he states in one of the most fascinating sections of Vom Sinn der Sinne, is unlike colour, which adheres to the coloured object, which accompanies its profile, conferring sight its characteristics of sharpness and cleanness. Sound has an autonomous existence. It does not adhere to its source, but it reaches, clutches, and grasps the listener. It fills space, but has no place. From this comes its power, and its capacity of imposing itself on us. From this comes his ineluctability, which, Straus notes in his Phenomenology of Hallucinations (p. 229) $)^{3}$, is confirmed by the fact that the words for "hear and obey", in Greek and Latin, in Hebrew, in French, German and Russian all come from the same root. (English is no exception, he continues, for the verb "to obey", and the noun "obedience", stem from the Latin "obauire": literally, "to listen from behind".)

A suggestive passage of On Obsession is dedicated to the relationship between subject and things, between the ego and the alter, their links to the phenomenon of the voice and its characteristic insituability and ineluctability. "The relation My-Own/The-Other is a permanent theme of all experience", Straus remarks; but, even if "My-Own is opposite to The-Other", he continues, "this opposition is no absolute one. My voice belongs to me; nevertheless, in speaking I hear myself; my voice is reflected back to me and thus far it is similar to a sound which originates from The-Other."

3. See also E.W. Straus. Aesthesiology and hallucinations, p. 159-60. 


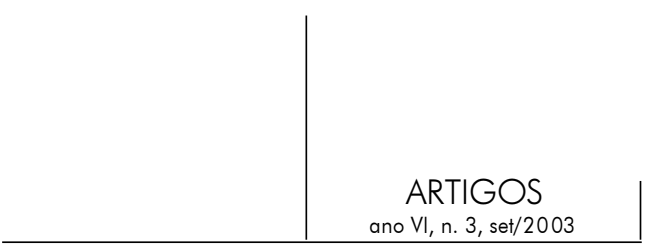

This constitutive doubleness, this insoluble ambivalence may perhaps be a reason for the power that all sorts marginal figures of women and men - witches and sorcerers, healers and crazymen, fools and, and even children - have always perceived and attributed to the voice, the word, the name. The Other is already and always inside the Identical: his voice already and always breaks the continuity and transparency of my voice; my voice is the voice of the Other, says Straus, that resounds and returns to me; and in this movement only does it become my voice, in this movement I become the I that I am, that speaks and that is spoken by his (or my, now) words. The voice gives birth to subjects and brings to light objects. It means sovereignty, sovereignty of the subject on the subject itself and on the object; and its failure means the failure of the order of the I, and of the world of objects I govern.

Here again, is, the root of that enigmatic experience of coincidence of things and words, names and persons, that psychopathologists and ethnologists so often observe without fully understanding it. Here is the reason why the possession of the very name of a warrior of the enemy tribe is to possess his existence, so a warrior must have two names, one of which, the secret one, is as precious as life. And here is the reason why pronouncing or writing, reading or touching the word "death" in a conversation, a letter or a newspaper is already contagion, for the obsessive, for the phobic, and a promise of decay, the threat and fascination of decease.

"The effect of such words", concludes Straus,

... is certainly not less shocking than that of the things themselves. Against the attacks of the evil things a defense still appears possible. Against the Word there is no defense. One cannot turn away from it. It follows and gets through the narrowest pores... Sound is a pursuer. It can be a persecutor. The acoustical substance in which language is formed bestows on the word a magic power to which the obsessive succumbs. (1948, p. 35)

Or, as we shall see, to which the obsessive oppose other magic powers, other spells, other enchantments.

\section{6 - "Their indetermination expresses itself in a presence that is "everywhere""}

The irreparable loss of the name coincides with the experience of the ubiquity of dreadful, ungraspable things: the monotonous rigor of the obsessive deciphers signs and menaces everywhere. Nothing can contrast the repugnant, 


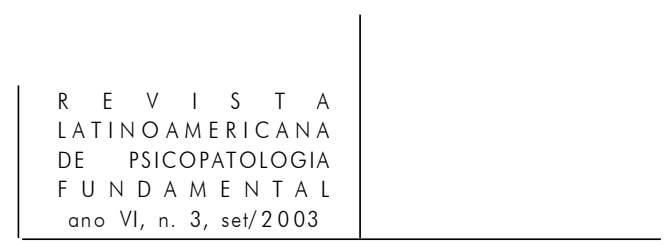

nothing survives of vital and desirable: "The world of the obsessive has lost such polaric articulations"; it is, says Straus, "a world that grows homogeneous because of the omnipresence of decay" (Ibid., p. 19)

The obsessive is therefore incapable of acting, he continues, and incapable of concluding his actions. Better still, he wants to undo what he has done. For only in an uneven, variegated world are gestures and actions possible: "only in a heterogeneous space, where one direction is better than any other one" (Ibid., p. 30-1). A world which is met in the unique, infinitely insistent enchantment of the obsessive theme - "as decay, disease, dirt, as death, corpse, decomposition, as germs, dust, mud, as excretion, urine, faeces, as sweat, sperma, sputum" (Ibid., p. 19) - does not allow any intentionality. The world itself abandons the torpor of everyday's experience. It comes to life. It now has its own intentionality. Everything appears as hierogliphics offered for painful deciphering by the obsession, in the fascination of what Straus calls the unique, peculiar "physiognomy" of a phobia. Everything becomes sharp, for example, and pointed: a whole world of blades and knives. Or it becomes contagious and sick. Or populated by animals, and insects...

\section{7 - "Obsessives are magicians of a brand of their own"}

"Physiognomical characters", Straus writes, "have no precise localization nor a definite delineation; their spatial indetermination is translated into an 'everywhere', the lack of definite delineation into a 'reaching beyond any distance"." "They seem to spread, they are contagious" (Ibid., p. 37). So, the phobic's every gesture is destined to checkmate. But it would be wrong to say that he therefore does not act at all. Action is impossible in phobia, but at the same time it survives. It survives in a absolutely peculiar and fascinating form, that bears witness, in a way, to the tragic shrewdness of phobic and obsessive patients. The obsessive, sunk in an implacably hostile world, reacts to spells with other spells, and fights the enchantment that obsesses him by means of new enchantments.

Expedients and tricks that smack of magic - an anthropological category whose interpretation was particularly congenial to Straus, starting with his early work Zur Psychologie des Okkultismus (1924) - are in fact not rare in obsession. Not only the dimension of the voice, the word, the language, but also the number, the ritual, the numbered repetition of gestures, the stiffening of actions in their double or triple reproduction, mark out the rhythm and the atmosphere of obsessive experience, and brand the obsessive's action as defensive, but at the same time agonizing cyphers. 


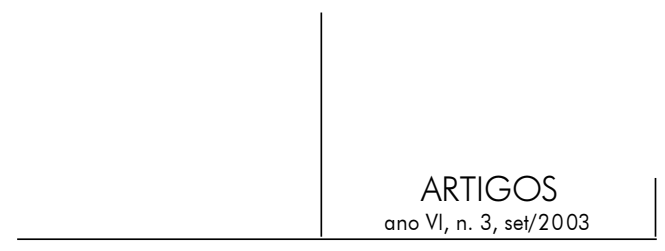

A patient Straus describes in On Obsession, before starting to walk always looks for "a position that guarantees that he will step forward in a direction opposite to that pointing to the cemetery". Another can't cross the threshold of her room without a certain ritual: "she sets a foot down, the toes pointing away from the room of another girl whom she hates fervently. After having repeated this movement three times she can turn in any direction." A third patient, before leaving his room, is "compelled to sprinkle a few drops of water on the threshold", and "only when this libation has been spent does he feel sure enough" to leave the place.

In these and other cases, Straus comments, "the threshold has the function of the magic circle separating the sacred area from the profane. Therefore, it must not be crossed without magic precautions." It is thus the action itself, the gesture itself, as the constitutive threshold between the subject and the world, that the obsession revokes from its everyday, imperceptible taking place, and that he reproduces and can reproduce only by in-forming it through ritual, number, and repetition. "Without any common instruction, without communication among themselves", Straus remarks, "they develop identical techniques. The ritual of one patient frequently resembles that of another in minute detail." Rituals "grow spontaneously against the same dangers". Phobic patients all become, he concludes, "magicians of a brand of their own" (Ibid., p. 38).

As words keep the experience under their law, at the threshold between nameable and un-nameable, so numbers rule over gestures, inscribing them in a superior measure or order: the order of the rite, a kind of "anti-enchantment", Straus says, that the obsessive formulates "against the enchantments" he is fighting. Gesture and number communicate to each other their substance, their essence, giving birth to the peculiar form of the experience of obsession.

\section{8 - "Numbers are not abstract symbols"}

In his patient Frances U.'s life, Straus writes, the numbers five and three played an essential role. "She had to touch things three times; she had to reread the last three lines on a page three times; according to her, five was the number of the members of her family: mother, two aunts, a brother, and the patient. Three signified the family without the aunts, whom she hated, and in another version she related number three to the three parts of male genitalia."

But what interests Straus is the pure form of the repetition - the numbered reproduction of gestures in itself, the empty eidos of ritual, which is irreducible to its psychological content, meaning, and origin. Eidos that is something pre- 


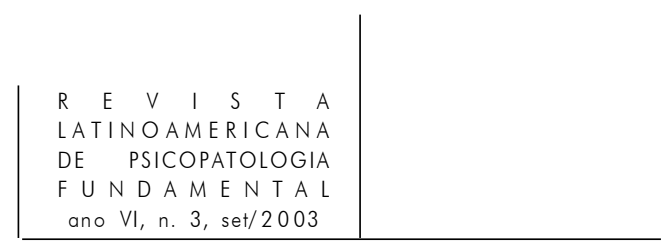

psychological, that gives birth to the kind of experience we know by the greek word psyché, but which is in fact much more ancient than its psychological interpretation or mis-interpretation, and is its transcendental condition of possibility. What about the general form of the number, the ritual, the repetition - what about its peculiar content as a pure form?

Obsession, Straus maintains, more than having to do with the biographical dimension of a patient's history, shows, with the strength of its tragical radicalization, the phenomenological consistency and the transcendental productivity of the number, the repetition, or the ritual as pure structures of everybody's and everyday's experience. It shows the content of the form of numerability, of ritual, of repetition. "Repetition", we read in On Obsession (Ibid., p. 39), "removes spontaneity and simplicity of action." Through repetition, "action become formalized." Repetition "is cumbersome, yet numbers are finite". So it is by means of numbers that repetition (which is per se indefinite, and potentially infinite) becomes practicable again. "With a preestablished number of repetitions an end is sight, and action may become final"; and by becoming final, action regains its own limit, and its own possibility.

Numbers, then, "are not abstract symbols", but enchantments of action that respond and correspond to evil because they are similar to it. Therefore they work. Therefore they fail.

They fail, because the exact measure of repetition, "which should help in action, may become a new obstacle". The magician's spell finally reveals itself as ineffectual. As poisons at times become a remedy, remarks Straus, so remedies may turn themselves into poison. Every one of his actions needs to be assured by another action, every ritual to by another ritual, again and again. The obsessive abandons the free vertical event of the action, its original, instant enchantment, for its horizontal, illusory figures - for its infinite postponement. Till that last mask, that last fascination that is the suspension of all action: death.

\section{References}

Brown, N.O. Life against Death. The Psychoanalytical Meaning of History. New York: Vintage Books, 1959.

Gebsattel, V.E. von. Die Welt des Zwangskranken. Monatsschrift für Psychiatrie und Neurologie, 99, p. 10-74, 1938.

ShaKespeare, W. Troilus and Cressida, V/III. In: Complete Works. Oxford: Clarendon Press, 1992.

Straus, E.W. On Obsession. A Clinical and Methodological Study, Nervous and Mental Disease Monographs, New York 1948, p. 7-8. 


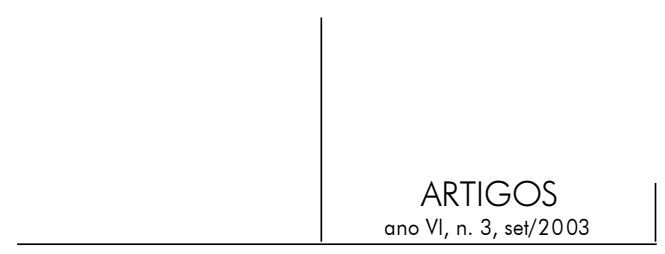

Vom Sinn der Sinne. Ein Beitrag zur Grundlegung der Psychologie. Heidelberg: Springer, Berlin-Göttingen, 1956.

Aesthesiology and Hallucinations. In: May, R., Angel, E., Ellenberger, H.F. Existence. A New Dimension in Psychiatry and Psychology. New York: Basic Books, 1958.

Phenomenology of Hallucinations. In: West, L.J. (ed.). Hallucinations, ed. by New York-London: Grune \& Stratton, 1962.

Swift, J. The lady's dressing room. In: The Complete Poems. New Haven: Yale University Press, 1983.

\section{Resumos}

O autor apresenta "Psicopatologia da fobia e da obsessão," de Erwin Straus (com referência a seus textos On Obsession [Sobre a Obsessão], Phenomenology of Hallucinations [A Fenomenologia das Alucinações], e Von Sinn der Sinne). As implicações sobre o papel da linguagem e do gesto na constituição (e na crise) das experiências da subjetividade e da objetividade são abordados.

Palavras-chave: Obsessão, fobia, fenomenologia, Straus, linguagem, sujeito, mundo

El autor presenta la psicopatología de la fobia y la obsesión de Erwin Straus (con referencia a su texto On Obsession, Phenomenology of Hallucinations, and Vom Sinn der Sinne) trayendo a luz las implicaciones concernientes al rol del lenguaje y los gestos en la constitución (y las crisis) de las experiencias de subjetividad y objetividad.

Palabras claves: Obsesión, fobia, fenomenología, Straus, lenguaje, sujeto, mundo

L'auteur présente la psychopathologie de la phobie et de l'obsession de Erwin Strauss (avec des références à ses textes On Obsession, Phenomenology of Hallucinations, et Vom Sinn der Sinne), mettant en lumière les implications relatives au rôle du langage et de la gestuelle dans la constitution (et la crise) de l'expérience de la subjectivité et de l'objectivité.

Mots clés: Obsession, phobie, phénoménologie, Straus, langage, sujet, monde 